\title{
Artifacts from 41SA38 in the Texas Archeological Research Laboratory Collections
}

Timothy K. Perttula

Heritage Research Center, Stephen F. Austin State University

Follow this and additional works at: https://scholarworks.sfasu.edu/ita

Part of the American Material Culture Commons, Archaeological Anthropology Commons, Environmental Studies Commons, Other American Studies Commons, Other Arts and Humanities Commons, Other History of Art, Architecture, and Archaeology Commons, and the United States History Commons

Tell us how this article helped you.

This Article is brought to you for free and open access by the Center for Regional Heritage Research at SFA ScholarWorks. It has been accepted for inclusion in Index of Texas Archaeology: Open Access Gray Literature from the Lone Star State by an authorized editor of SFA ScholarWorks. For more information, please contact cdsscholarworks@sfasu.edu. 


\section{Artifacts from 41SA38 in the Texas Archeological Research Laboratory Collections}

\section{Creative Commons License}

\section{(c) (1) \&}

This work is licensed under a Creative Commons Attribution-NonCommercial 4.0 International License 


\title{
Artifacts from 41SA38 in the Texas Archeological Research Laboratory Collections
}

\author{
Timothy K. Perttula
}

Site 41SA38 (ET-692) was recorded in February 1940 by Gus Arnold of the University of Texas as part of the WPA-sponsored archaeological survey of East Texas (Perttula 2016a-b). The site was identified on a natural alluvial rise in a freshly plowed floodplain on the west side of Ayish Bayou, about $1 \mathrm{~km}$ southwest of the city of San Augustine, Texas.

During Arnold's survey investigations, he collected a few surface artifacts over the ca. 0.5 acre alluvial rise. The artifacts in the Texas Archeological Research Laboratory at The University of Texas at Austin collections include three aboriginal ceramic sherds and a gunflint.

Two of the aboriginal ceramic sherds are plain body sherds from bone-tempered vessels; the thickness of the sherd body walls range from 5.1-8.6 mm, indicating they are from different vessels. The third sherd is a bone-tempered rim sherd $(6.9 \mathrm{~mm}$ thick) from a jar with an everted profile and a rounded lip. The jar rim has horizontal brushing marks. The use of bone temper in the three sherds from 41SA38 is consistent with the heavy use of bone temper in previously studied ceramic assemblages from the nearby Mission Dolores (Avery 2016:59).

The gunflint is a spall type made from a blonde-yellow or beeswax chert or flint that likely originates in France (Hamilton 1979:210). Avery (2016:73) notes a few small chips from gunflints at Mission Dolores from the same blonde-yellow flint. The gunflint is $21.0 \mathrm{~mm}$ in width and $22.1 \mathrm{~mm}$ in length, with a $19.0 \mathrm{~mm}$ working edge; the heel is about $7.0 \mathrm{~mm}$ wide, and the gunflint itself is $8.7 \mathrm{~mm}$ thick. There are several flake scars on the dorsal surface.

\section{References Cited}

Avery, G. E.

2016 Mission Dolores Replication Project: Geophysical Survey and Shovel Testing, May 2008. Stephen F. Austin State University Press, Nacogdoches.

Hamilton, T. M.

1979 Guns, Gunflints, Ball and Shot. In Tunica Treasure, by J. P. Brain, pp. 206-216. Peabody Museum of Archaeology and Ethnology, Harvard University, Cambridge, Massachusetts and the Peabody Museum of Salem, Salem, Massachusetts.

Perttula, T. K.

2016a Caddo Ceramic Assemblages from Sites in the Ayish and Palo Gaucho Bayou Basins, San Augustine County, Texas. Journal of Northeast Texas Archaeology 70:13-31.

2016b Artifact Assemblages from San Augustine County, Texas, Sites Recorded in 1939-1940 by Gus E. Arnold. Journal of Northeast Texas Archaeology 72:75-134. 